\title{
HOLISTIC APPROACH TO THE IMMUNOBIOLOGY OF AGING (VIEW ON THE TURN OF MILLENIUM)
}

\author{
Branko Vitale ${ }^{1}$ \\ ${ }^{1}$ Academy of Medical Sciences of Croatia
}

\begin{abstract}
SUMMARY - Among many functions of the body affected by the complex process of aging, the immune system, primarily due to declining of thymic function, the ancient and conserved evolutionary process, undergoes complex remodelling in the second part of life, with recapitulation of inversely evolutionary pattern of the immune system. In approaching the complex analysis of age-associated derangement of the immune system, homeostasis, and its clinical consequences, classical monoclonal lymphoproliferative syndrome (CLL) accompanied by a myriad of cellular and humoral defects, has been selected as appropriate and useful model for studies of impact T-cell and B-cell defects on appearance, evolution of clinical manifestations and outcome of CLL syndrome. Therefore imbalance in cascade secretion of a number of Th-1 (pro-inflammatory cytokines) and/or Th-2 (anti-inflammatory cytokines) in CLL patients with their pleiotropy, redundancy, synergistic and antagonistic activity and parallelism can cause variety of clinical manifestations as recurrent infections, systemic inflammation/ sepsis, immunodeficiency, autoimmune disorder, indolent antiself malignancy, and/or other diverse secondary tumours.
\end{abstract}

Key words: aging, immune system, cytokines, thymus, $T$ and B lymphocytes

\section{Prologue}

Among many functions of the body affected by the complex process of aging, immunosenescence, primarily due to the declining thymic function, undergoes a complex remodelling in the second part of life. In addition, aging is a dynamic and adaptable process controlled not only by genes, but also by environmental, socioeconomic and life style factors.

\section{Genetic and Ecological Aspects of Aging}

nothing in biology makes sense

except in the light of evolution

(Theodosius Dobzhansky 2000)

\footnotetext{
Correspondence to: Prof. dr. sc. Branko Vitale, Academy of Medical Sciences of Croatia

e-mail: bvitale@irb.hr
}

\section{Theories}

According to evolutionary theories, aging is a process tightly controlled by genetic and environmental factors, in combination with current physiological state(s), evolving directly from the phase of development and maturation. In contrast, stochastic theories propose that aging is the result of the wearing out of the organism, emphasizing the importance of the epigenetic and environmental factors predominating in the second part of life. Postulated molecular mechanisms include decreased DNA repair capacity resulting in the cumulative DNA damage and genome instability, modifications of subcellular structures that may alter gene expression patterns, telomere shortening in replicative cells and oxidative damage of vital macromolecules responsible for functional decline in different tissues and organs. Finally, free-radical theory proposes that the aging process depends on chemical reactions within normal metabolism even if environ- 
mental or other external conditions are generally optimal. Since the aging process is not subjected to natural selection, it may not be necessarily controlled by specific gene sequence(s). Three repetitive processes chronic stresses, metabolic and proinflammatory responses, in combination with current physiological state(s), which are in essence epigenetic processes, by provoking various degree(s) of cellular and tissue damages, could be essential for distraction and disruption of dynamic homeostasis of the human beings. This possibility is further supported by the fact that average life expectancy has been increasing in spite of decreased body complexity together with declining functions of the immune system. Namely, contemporary advances in medical sciences, socioeconomics, massive vaccination and nutrition resulted in a dramatic increase in human life expectancy to unprecedented average of 80 years. Thus, living organisms, as complex biological systems have been driven mainly by internal forces - by the pure phenomenon of life.

To conclude:

The harmonius cooperation of all beings arose not from the orders of a superior authority external to themselves but from them, fact that they were all parts in a hierarchy of wholes formating a cosmic pattern and what they obeyed were internal dictates of their own natures.

(Chijang Tze, third century BC)

\section{Immunobiological Aspects of Aging}

\section{The story of immunity is the story of self. The immune system creates, records and protect our individuality}

(Irun Cohen 2000).

\section{The Immune System}

The immune system participates in protection against external hazards (infections with viruses, bacteria, parasites and allergens), internal hazards (antiself reactivity and surveillance against tumours) and plays a crucial role in the pathogenesis of practically all diseases. Among many functions of the body affected by the complex process of aging, the immune system, primarily due to declining thymic function, an ancient and conserved evolutionary process, undergoes complex remodelling in the second part of life, with recapitulation of inversely evolutionary pattern of the immune system. Genetic and behavioural individuality of human beings is integrated, coordinated and functionally regulated by continuous conversations at intracellular, intercellular, and organ level. Furthermore, human beings are maintained in dynamic stationary states as thermodynamically open systems with the self-organization, complexity, emergence of new order, and adaptation. Complex system behaviour, responsible for system stability and better adaptability to daily perturbations, emerges spontaneously from its basic structures with new properties that are not a simple sum of individual properties. Immune reaction represents a complex series of cellular events responsible for functional reactivity and enhancement of functional effectiveness of the system. By permanent activity of various humoral and cellular mechanisms receiving and transmitting enormous variety of excitatory and/ or inhibitory signals, immune system permanently reacts to any disruption of tissue and/or body integrity. In addition, the immune reaction is strictly controlled and depends on timely and balanced secretion of a number of cytokines with agonistic and antagonistic effects which then act upon different effector and bystander cells within the immune system.

Cytokines create an immune system dynamic homeostatic network, which is composed of a number of small glycoprotein messenger molecules that interact in a non-linear fashion. Any imbalance in cascade secretion of a number of Th-1 (pro-inflammatory cytokines) and/or Th-2 (anti-inflammatory cytokines) with their pleiotropy, redundancy, synergistic and antagonistic activity and parallelism can cause a variety of clinical manifestations, primarily as increased susceptibility to infections.

Two coexisting homeostatic mechanisms regulate the basic functional activity of the immune system: linear dynamic mechanism with the magnitude of response regulated by activation of negative feedback loop proportional to strength of stimuli (dose response) and non-linear dynamic mechanism with small changes in initial conditions that can provoke unanticipated abrupt effects and rapid amplification magnitude to full dynamic range of the system, resulting in diverse chaotic behaviour. Chaotic behaviour can be manifested clinically by recurrent and/or systemic explosion of inflammatory reaction accompanied by multiple organ dysfunctions and/or compensatory anti-inflammatory reaction syndrome and severe immunosuppression (systemic implosion). Transition between dynamic homeostasis to chaotic behaviour within the network of 
immune system can be provoked by a bias of cellular interactions and imbalanced cytokine secretion. When trivial degrees of the built-in control switch in the immune system, they can generally significantly contribute to good or bad clinical prognosis.

\section{Factors Responsible for Disfunction of Age-Associated Derangement of Homeostasis of the Immune System}

Biological polymorphism of regulatory genes or structural changes in affected genes by built-in restrictions of their genetic programs.

Environmental conditions (chronic infections) compromise certain vital links in over-driving the immune system by disproportion between persistent antigen load and duration of antigenic stimulation and the capacity of homeostatic immunoregulatory mechanisms.

Thymic age-related reduction of functional capacity of genetic programs in organ microenvironment to support differentiation and bidirectional functional maturation of phenotypically triple negative thymocytes into T-cells and of B-1 cells lineages, are the dominant factors responsible for impaired homeostasis of the immune system. Various subtle defects in genetic repertoire in thymus may restrict or even block regular differentiation and functional maturation of common lymphoid progenitors. Thus, for instance, diverse combinations of immature and mature markers found on CLL T-cells and B-1 cells might in turn reflect various subtle defects in thymus-stromal cell interactions responsible for their ineffective maturation.

\section{Chronic Lymphocytic Leukemia (CLL) \\ - a Case Study of Laboratory and Clinically Integrated Model Analysis of Disrupted Homeostasis of the Immune System}

\section{Clinical Model}

In approaching the complex analysis of age-associated derangement of the immune system homeostasis, and its biomedical consequences, classical monoclonal lymphoproliferative syndrome (CLL), accompanied by a myriad of cellular and humoral defects, has been selected as appropriate and useful model for longitudinal clinical studies. Namely, because of a relatively slow natural evolution, CLL is further convenient for longitudinal studies and analysis on how natural evolution of different molecular and cellular abnormalities within the immune system, could influence the emergence and expansion rate of leukemic B-1 clone.

\section{Natural History}

CLL is the most common leukaemia in Western hemisphere, it often begins insidiously in mid-life, but rarely under age of 40 (premature aging?).

In adults it comprises about $30 \%$ of all clinical cases related to lymphoproliferative group of diseases. The median age of clinical diagnosis of CLL is between 65-75 years of age; thereafter the incidence of CLL increases exponentially with age.

\section{Clinical Characteristics}

- slowly emerging accumulation of morphologically indistinguishable, functionally and metabolically inert clone of B-1 cells in the peripheral blood, bone marrow, lymph nodes and spleen, which did not retain the capacity to activate in vivo apoptosis

- depending on the level of blockade of their post germinal centre differentiation B-1 cells might secrete putative anti-self antibodies with specificities against own subcellular components

- often myelopoietic failure

- impairment of various immunological functions

- frequent hypogammaglobulinemia

- unique immunodeficiency among lymphoproliferating diseases -

- imbalance among various T- cell subsets with dominance of $\mathrm{CD} 8^{+} \mathrm{T}$ - cells in the peripheral blood

- by coexpressing of $\mathrm{CD}^{+}$and $\mathrm{ME}^{+}$receptors both on T-cells and B-cells which in heathy subjects are exclusively expressed in either one of them (lineage infidelity)

- autoimmune haemolytic anaemia and thrombocytopenia

- possible development of secondary tumours

- remarkable variability in clinical presentation, course and prognosis.

\section{T-Lymphocytes}

T-lymphocytes are central effectory and regulatory cells of the immune system exerting their immunoregulatory function by a number of cytokines they secrete and by a number of immune synapses (transient 
cell to cell complexes) formed and dissolved as information, and are transmitted within the immune network. T-lymphocyte compartment in the peripheral blood of CLL patients is deeply affected. Increased absolute number of T-cells is accompanied by reversed $\mathrm{CD}^{+} / \mathrm{CD}^{+}{ }^{+} \mathrm{T}$-cell ratio, functionally insufficient helper $\mathrm{CD}^{+}$cells, and domination of cytotoxic/suppressor $\mathrm{CD}^{+} \mathrm{T}$-cells, appearance of immature double $\mathrm{CD}^{+}{ }^{+}$and $\mathrm{CD}^{+} \mathrm{T}$-cells, and disproportion between naive and memory $\mathrm{T}$-cells with accumulation of differentiated effector memory CD45RA ${ }^{+} \mathrm{T}$-cells and reduced production number of new naive $\mathrm{CD} 45 \mathrm{RO}^{+}$ T-cells.

In addition, gradual development of different functional T-cell defects in CLL is characterized by their progressively reduced in vitro seeding efficiency and progressively reduced metabolic activity.

\section{Leukemic B-1 Lymphocytes}

In contrast to domination of conventional polyclonal B-2 lymphocytes in healthy subjects, in CLL patients, due to expansion of leukemic B-1 cell clone, mono- or oligoclonal B-1 lymphocytes dominate in the peripheral blood. B-1 cells with expression of $\mathrm{CD}^{+}$molecule are a part of innate immunity-producing low-affinity antibodies with reduced repertoire, impaired affinity maturation and decreased clonal diversification, producing polyreactive low affinity autoantibodies against self/natural antigens. B-1 cells on their surface simultaneously coexpress differentiation, immature and activation antigens accompanied by functional asynchronism between activated phenotype and cycle position of predominantly resting leukemic cells. Chaotic behaviour of leukemic B-1 lymphocytes is further characterized, due to imbalance of Th-1 lymphocytes and increased IL-4 cytokine secretion, by upregulation of bcl-2 and deregulation of c-myc protooncogenes, and loss of tumour suppressor gene activity p53 responsible for suppression of their in vivo apoptosis. Finally, B-1 cells with leukemic phenotype could be detected in about $2 \%$ of healthy subjects over the age of 40 and about $8 \%$ over the age of 70 , remaining in dormant state in the majority of healthy subjects during their entire life.

\section{Pathogenesis}

In recent years significant progress has been made in immunological and molecular biology methodolo- gies that opened new vistas on the complex CLL pathogenesis. Accordingly, impaired and functionally imbalanced T-cell subpopulations accompanied by uneven profiles of their cytokine secretion may lead to inadequately matched activation of various protooncogens, defective differentiation and/or blockade of programmed cell death that may end up in eventual emergence of a malignant B1-cell clone accompanied by a myriad of cellular and humoral immunological defects. Along with the imbalance among immunoregulatory $\mathrm{CD}^{+}$and $\mathrm{CD}^{+}{ }^{+} \mathrm{T}-$-cells, additional activation of neuroendocrine axis may also profoundly influence their behaviour relevant to CLL pathogenesis.

Namely, hypophyseal-pituitary-adrenal axis activated by acute or chronic stress response or chronic antigenic load may cause shift of Th- $1 /$ Th- 2 balance towards Th-2 lymphocytes, while age related declined secretion of stromal cell enzymes and thymic hormones may cause progressive weakening of the Th-1 lymphocytes activity. By exerting various cross-regulatory or inhibitory effects and uneven secretion of Th- 1 or Th-2 cytokines may in turn further distract their production and trigger a series of events which might end up in clinical manifestations of CLL. In addition, under these circumstances generally proinflammatory status might be the predictor of increased morbidity, physical disability and mortality risk rate among CLL patients.

\section{Clinical Epidemiology \& Biostatistics}

Statistical and/or mathematical analysis of the distribution of different cellular markers on both $\mathrm{T}$-cells and B-1 cells could represent a powerful tool in studying of the clinical variability of CLL. Namely, marker(s) associated with the prognosis are probably associated with the biological characteristics of the disease. That is, any event or events associated with prognosis are also very likely to be associated with pathogenesis of the disease.

\section{TTM Staging System}

By measuring well defined and reproducible parameters such as total tumour mass (TTM) and rate of its doubling time (DT), CLL patients could be divided into two clinically and prognostically distinct groups i.e. low risk stable CLL (indolent antiself malignancy) with survival of about 20 years and high risk 
progressive CLL with significantly shorter survival (1-2 years). However, not until the introduction of TTM scoring system (by measuring shortening of DT of TTM) the relationship between impaired T-cell functionally activity and progression rate of CLL can be adequately documented.

\section{Systems Biology Methodology}

In contrast to the classical reductionist approach, where only a few already recognized variables can be evaluated, a systems biology methodology is based on a composite analysis of all interconnected components in biological system which could be responsible for defining possible function(s) of created phenotypes. Based on this information, data are collected and integrated into a model by mathematical description of the system. The final aim of the created protocol is to develop a statistically significant model that can accurately predict responses to changes within the system. By using nonlinear decision tree machine learning C.4.5 method, database comprising 32 different phenotypic parameters revealed only three of them, along with concentration of soluble CD23 molecules in sera, in having predicting values. But only if these three phenotypic single parameters concatenated as a composite vector, could then the CLL patients be correlated and distinguished into low, intermediate or high risk groups with different degree of accuracy.

\section{Non-Linear Volterra Equation Mathematical Model}

Finally, non-linear Volterra equation mathematical method has been introduced in order to validate the importance of different biological interactions and/or communications along quantitative relationship between different peripheral blood T-lymphocyte subsets and leukemic B-1 lymphocytes in predicting progression rate of CLL. The significance of Volterra nonlinear equations lay in its ability to predict from given initial quantitative relationship between composition of different T-lymphocyte and B-1 lymphocyte compartments and structure of their subsets, and the possible time course of disease leading to low or high speed pathway of CLL. Depending on the initial conditions, the temporal behaviour of T and B-1 lymphocyte compartments and their subsets, they can be ei- ther dynamically stable showing oscillatory character or dynamically unstable showing, in case of CLL, progressive increase in the number of B-1 leukemic cells. In addition, epigenetic and life style factors, by influencing dynamic and variable relationship between different T-cell and B-1 cell subsets, in combination with imbalance in their mutual bidirectional communications, might generally dictate oscillatory remission/relapses in chronic autoimmune diseases.

In conclusion, chronic lymphocytic leukaemia, due to decreased body complexity, might be only one of the possible reflections of complexly disrupted homeostasis of the immune system which could be clinically manifested as recurrent infections, systemic inflammation/sepsis, immunodeficiency, autoimmune disorder, indolent antiself malignancy, and/or other diverse secondary tumours. Finally CLL could also be a simple product of aging and longevity.

\section{Epilogue}

Whether or not the aberrant intracellular and/or intercellular homeostatic mechanism(s) would propagate pathogenetic events in the direction of CLL as evolutive nonlinear process can only be expressed as probability magnitude which depends on a number of various conditions. Besides the genetic background, great variability in the course and prognosis of aging processes in elderly patients and their current physiological state is additionally influenced by environmental factors, including life style in combination with historical and cultural influences, environmental justice, environmental equity, health-care accessibility and medical care compassion.

\section{Post Scriptum}

Having the complexity of biological systems in mind, Sir Macfalane Burnet (Nobel prize winner) postulated the first Darwinian type statement in immunology as early as 1972

...that everything in immune phenomena is soft-edged. There is no clear absolute whether or not a given reaction occurs when cell meets antigen can be only expressed as a probability whose magnitude depends not only of factors that in principle might be expressed definitely but on many others that are virtually as complex at cellular level as the genetic and ecological factors which determine the course of evolution at the macro-level. 
...that in the universe of circulating cells of the body we find something analogous, though strictly limited in space and greatly accelerated in time, to the interacting species in a terrestial ecosystem as they evolve under the changes and chances of million years.

\section{References}

(extensively quoted a number of our group papers related to the subject)

1. Jakšić B, Vitale B, Total tumor mass score (TTM): A new parameter in chronic lymphocytic leukemia British Journal of Haematology 1981, 49:405-367.

2. Vitale B, Antica M, Benković B, Burek B, Jakšić B, The relationship between membrane characteristics, functional reactivity of T-lymphocytes and progression rate of B- cell chronic lymphocyic leukemia Cancer 1984, 56:1073-1081.

3. Antica M, Jakšić B, Vitale B, T-lymphocyte colonies from patients with chronic lymphocytic leukemia (CLL) Periodicum biologorum 1986, 88: Supp 1/A 503-504.

4. Jakšić B, Vitale B, Chronic Lymphocytic Leukemia: A model for Studying Immunoproliferative Diseases Blood cells 1987, 12: 281- 283

5. Benković B, Burek B, Jakšić B, Vitale B, Modulation of Chronic lymphocytic leukemia (CLL) by in vitro incubation with alpha-1 thymosin Blood cells 1987, 12: 441-451.

6. Jakšić B, Vitale B, Hauptman E, Planinc-Peraica A, Vitale B, The role of age and sex in the prognosis of chronic leukemias: A study ot 373 cases British Journal of Cancer 1991, 64 : 345-348.

7. Antica M, Kušić B, Spaventi R, Jakšić B, Vitale B, Functional differences of T- cells in B-cell Chronic Lymphocytic Leukemia Leukemia and Lymphoma 1993, 9: 133-40.
8. Poljak LJ, Šimaga Š, Jakšić B, Vitale B, Modalities of in vitro $\mathrm{IgM}$ and IgG Producton by Peripheral Blood Lymphocytes of Chronic Lymphocytic Leukemia Patients and Healthy Volunteers Leukemia and Lymphoma 1993, 9: 357-364.

9. Vitale B, CLL a paradigm for developmental imbalance in $\mathrm{B}$-cell and T-cell communication Update in Haematology/ Oncology IV EORTC Wienna 1995, 39-44.

10. Gagro A, Dašić G, Sabioncello A, Rabatić S, Reckzeh B, Haveman K, Kardum I, Jakšić B, Vitale B, Phenotypic analysis of receptor-ligand pairs on $\mathrm{B}$-cell in B-cell chronic lymphocytic leukemia. Leukemia and Lymphoma 1997, 25: 301-311.

11. Mašić N, Gagro A, Rabatić $S$, Sabioncello A, Dašić G, Jakšić B, Vitale B, Decision-tree approach to immunophenotype-based prognosis of the B-cell chronic lymphocytic leukemia American Journal of Hematology 1998, 59: 143-148.

12. Svoboda-Beusan I, Kušec R, Bendelja K, Tudorić-Ghemo I, Jakšić B. Pejša V, Rabatić S, Vitale, B. The relevance of multidrug resistance-associated $\mathrm{P}$-glycoprotein expression in the treatment response of B-cell chronic lymphocytic leukemia Haematologica 2000, 85: 1261- 1267.

13. Vitale B, Martinis M, Antica A, Kušić B, Rabatić S, Gagro A, Kušec R, Jakšić B, Prolegomenon for Chronic lymphocyti leukemia (CLL) Scandinavian Journal of immunology 2003, 58: 588-600.

14. Martinis M, Vitale B, Zlatić V, Dobrošević B, Dodig K, Vitale B, Mathematical model of B-cell chronic lymphcytic leukemia (CLL) Peridicum biologorum 2005.107: 445-450.

15. Majnarić LJ, Martinis M, Vitale B, Chronic lymphocytic leukemia (CLL) A syndrome of disrupted homeostasis of the immune system In Kniewald Z, ed. Current studies of biotechnology volume IV- immunomodulation Zagreb Medicinska naklada 2005, 83-94.

16. Majnarić-Trtica LJ, Vitale B, Systems biology as a conceptual framework for research in family medicine; use in predicting response to influenza vaccination Primary health care system and development 2011,12:310-321.

Sažetak

\section{HOLISTIČKI PRISTUP IMUNOBIOLOGIJI STARENJA (POGLED NA KRAJU MILENIJA)}

\section{B. Vitale}

Fiziološkom involucijom timusa i slabljenjem njegove kompleksne funkcije u drugom dijelu životnog vijeka dolazi do evolucijski uvjetovanog funkcionalnog remodeliranja imunosnog sustava. $U$ analizi starosno uvjetovane poremećene funkcije imunosnog sustava odabrali smo kao klinički model kroničnu limfocitnu leukemiju (KLL). KLL je vrlo pogodan model za longitudinalno prećenje uloge pojedinih imunoloških defekata u evoluciji patogeneze sindroma. Naime, neuravnotežena sekrecija proupalnih Th-1 citokina, protuupalnih Th-2 citokina, u kombinaciji s njihovom pleiotropijom, redundancijom, sinergističkom i antagonističkom aktivnošću i paralelizmom, može se klinički manifestirati kao rekurentne infekcije, sistemska upala/sepsa, imunodeficinjencije autoimuni procesi i sekundarni tumori i tako bitno utjecati na kliničke manifestacije, tok $\mathrm{i}$ ishod bolesti.

Ključne riječi: starenje, imunosni sustav, timus, T-limfociti, B-limfociti, citokini, kronična limfocitna leukemija 